\title{
Quaternary fluvio-lacustrine environments and human settlements in West Africa
}

N'dji dit Jacques Dembele

Bamako, Mali, 27-31 October 2014

The West African Quaternary Research Association (WAQUA) was established in 2009 to promote Quaternary Sciences in the West African region through the capacity building, mentoring and motivation of early-career scientists and the fostering of collaborative research, exchange of information and networking opportunities. Eighty quaternary scientists, mainly early-career scientists of the West African region and Democratic Republic of Congo, gathered in Bamako to share their research results and experiences on quaternary fluvio-lacustrine environments.

Fifty oral presentations were given in the following five sessions: (1) Quaternary fluvio-lacustrine sediments: paleoclimates and paleoclimatology; (2) Past and contemporary human settlements in relation to fluvio-lacustrine systems; (3) Paleoecological evidences from fluvio-lacustrine deposits; (4) Current environmental issues arising from the use of fluvio-lacustrine systems; (5) The methods of research of quaternary fluvio-lacustrine complexes in West Africa.

During the first session, the fluvio-lacustrine deposits of the Niger River in Mali and in Nigeria; the stratigraphy of fluvial deposits of the Falemé River, tributary of the Senegal River; and the paleoenvironment and paleoclimates of the Kivu River in the Democratic Republic of Congo during the late Pleistocene and Holocene were introduced. This session showcased the great potential to use fluvial deposits to reconstruct the quaternary climatic variation and paleohydrology of West Africa. However, because the scientists in that region do not use the same stratigraphic framework, comparing the individual studies is difficult. Building such regional comparable chrono- and climatostratigraphies is only possible through collaborative research efforts. In the discussion, the participants also agreed that local stratigraphic climatic stages such as the Ogolian (a dry period of the late Pleistocene) could not be generalized to all of West Africa without further research and stratigraphic correlation.

During the second session, the prehistoric settlement of the Sahelian region of West Africa in Burkina Faso, in the Niger Inland Delta region and in Nigeria; the Holocene settlement of the Dogonland of Mali; and the effect of current climate change on migration were presented. The discussion focused on the effect of quaternary climate variability on human settlements and population migrations. The participants recognized that understanding quaternary climate variation,

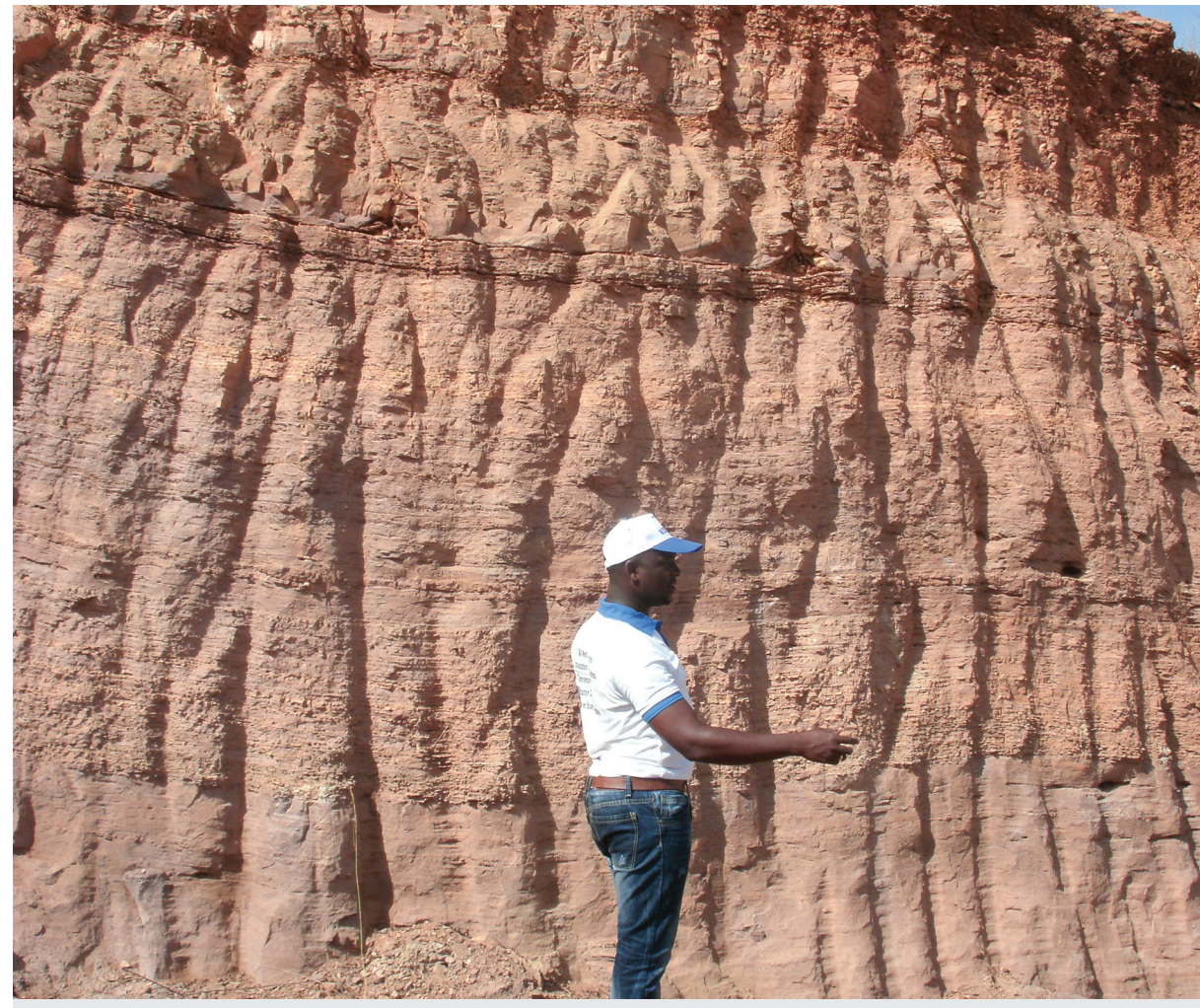

Figure 1: Laminated lacustrine deposits of the Niger River south bank at Bamako, Mali, visited during the conference field trip.

and especially the succession of dry and humid periods, should be one of the foci of quaternary research in the region.

The third session covered the evolution of quaternary vegetation in the Niger Inland Delta in Mali and in Nigeria and an explanation of the causes of the "Dahomey Gap", a region of savanna separating the West African tropical forests. Pollen analyses provide evidence of the effect of climate change and human settlement on West African ecosystems. The attendees recommended the use of more paleoecological research methods such as phytoliths and quaternary fossil assemblages analyses to complement pollen analysis.

The fourth session focused on the impacts of current climate change on the West African fluvial and lacustrine ecosystems; anthropogenic pressure; the use and management of fluvial and lacustrine resources; flash floods; the use of fluvial and lacustrine systems for tourism; and the impact of off-season rainfalls. In this session's discussion, the use of the concept of "climate change" was discussed and whether one can talk of climate change or climate variability in only a 30-year framework. Climatologists of the region were asked to address this question by providing a temporal perspective on the use of these two concepts in the West African context.

During the last session quaternary research methods in the West African fluvio-lacustrine context were discussed. Methods based on pollen analysis, computer modeling, and GIS were introduced.

To help the early-career scientists improve their research capacity, training sessions were organized on the topics "Paleoecology and palynology of quaternary fluvio-lacustrine deposits" and "The use of heavy minerals in quaternary fluvial and lacustrine deposits, and in geoarcheology".

\section{ACKNOWLEDGEMENTS}

The organizing committee express their sincere gratitude to PAGES, INQUA, PAST (Palaeontological Scientific Trust), AUF (Agence Universitaire de la Francophonie), and USSGB (Université des Sciences Sociales et de Gestion de Bamako) for their financial and material support, and encouragement.

\section{AFFILIATIONS}

'Faculty of History and Geography, University of Social Sciences and Management of Bamako, Mali

CONTACT

N'dji dit Jacques Dembele: ndjijacques@icloud.com 